J. Lake Sci. (湖泊科学), 2018, 30(6): 1599-1609

DOI 10. 18307/2018. 0611

(c) 2018 by Journal of Lake Sciences

\title{
东太湖水温变化与水一沉积物界面热通量初探
}

\author{
曾 野 ${ }^{1,2}$, 朱金格 $^{1}$, 王艳平 ${ }^{1}$, 胡维平 $^{1 * *}$ \\ (1:中国科学院南京地理与湖泊研究所湖泊与环境国家重点实验室,南京 210008) \\ (2: 中国科学院大学, 北京 100049)
}

\begin{abstract}
摘 要: 水温对沉水植被的生长和分布具有重要作用,水一沉积物界面热通量对浅水湖泊水温变化的影响值得关注. 东 太湖是我国东部典型的草型浅水湖区, 采用自 2013 年 11 月至 2015 年 10 月对东太湖湖心进行的不同深度水体及沉积物 温度高频观测数据, 结合东太湖表层沉积物的热力学性质计算了水一沉积物界面热通量, 分析了东太湖水温和水一沉积物 界面热通量的变化特征并探讨了其影响因素. 结果表明: 东太湖各深度水体日升温过程随水深增加后延, 升温过程夏季 延长, 冬季缩短; 表层水温日变幅最大, 底层水温日变幅次之, 沉积物温度日变幅最小, 各深度温度日变幅夏季最小、冬季 最大; 春季和夏季升温过程中各深度日均温变化沿水深存在约 1 天的延迟,秋季和冬季无此现象; 2015 年与 2014 年东太 湖温度变化趋势相同,同比月均温差与气温差呈线性相关. 沉积物 8:00-19:00 向水体放热增加或从水体吸热减少, 19:00 至次日 8:00 放热减少或吸热增加;3-9 月从水体吸热,为热汇, 10 月至次年 2 月向水体放热, 为热源, 沉积物全年 为湖泊热源;逐日水一沉积物界面热通量每月 6 至 15 日存在相对年变幅较小幅度的正弦式波动. 水温和水一沉积物界面 热通量的变化主要受太阳辐射和气温的影响, 二者对气象参数的响应具有迟滞现象;水一沉积物界面热通量与水温呈负 相关, 其变化相对水温迟滞, 水一沉积物界面热交换的主要作用为缓冲湖泊水体的热量变化; 夏季, 沉水植物能降低湖泊 各层水温和垂向水温差.
\end{abstract}

关键词: 热通量;水一沉积物界面;温度;高频观测; 东太湖

\section{Changes of water temperature and heat flux at water-sediment interface, East Lake Taihu}

\author{
ZENG Ye ${ }^{1,2}$, ZHU Jinge ${ }^{1}$, WANG Yanping ${ }^{1} \&$ HU Weiping ${ }^{1 * *}$ \\ (1: State Key Laboratory of Lake Science and Environment, Nanjing Institute of Geography and Limnology, Chinese Academy \\ of Sciences, Nanjing 210008, P.R. China) \\ (2: University of Chinese Academy of Sciences, Beijing 100043, P.R.China)
}

\begin{abstract}
Water temperature is critical for growth and distribution of submerged macrophyte and heat flux at water-sediment interface (WSI) is essential for water temperature changes. East Lake Taihu is a typical shallow macrophyte-dominated lake in eastern China. Temperatures of water and sediment at different depths were monitored with high frequency from November 2013 to October 2015 in the middle of East Lake Taihu. Heat flux at WSI was calculated with inferred thermodynamic parameters. Changing patterns of water temperature and heat flux at WSI were revealed and their influencing factors were discussed. Results showed that the temperature rising processes were delayed with the increase of water depth. Water temperature rising process was prolonged in summer and shortened in winter. Temperature ranges in averaged 24 hours: surface water temperature $>$ bottom water temperature $>$ temperature at WSI> sediment temperature. Temperature ranges in averaged 24 hours were smallest in summer and largest in winter. There was a 1-days' hysteresis of temperature changes along the water depth when the temperature rose in spring and summer, while not in autumn and winter. Annual trends of temperatures in 2015 was same with 2014, and differences of year-on-year monthly averaged temperatures were significantly correlated with differences of air temperatures. Heat absorption of sediment from water increased or its heat emission to water decreased from 8:00 to 19:00, while 19:00 to 8:00 next day in verse. From March to September, heat transferred from water to sediment, while from sediment to water from October to February next year. Sediment was heat source of
\end{abstract}

* 国家自然科学基金项目 (51279193) 和江苏省自然科学基金项目 (BK20151063) 联合资助. 2018-01-18 收稿; 201804-14 收修改稿. 曾野(1994 ), 男,硕士研究生;E-mail : marcochen94@ hotmail.com.

** 通信作者;E-mail:wphu@ niglas.ac.cn. 
East Lake Taihu in a whole year. Heat flux at WSI also had smaller 6-15 days' periodic fluctuations. Although changes of water temperature and heat flux at WSI were mainly affected by solar radiation and air temperature, they had delayed response towards meteorological parameters. Heat flux at WSI was negatively correlated with water temperature, and its change lagged behind water temperature change. The main function of heat flux at WSI was to buffer heat changes of lake. Submerged plants can relief surface water temperatures of lake as well as the vertical temperature gradients in summer.

Keywords: Heat flux; water-sediment interface; temperature; high frequency monitoring; East Lake Taihu

东太湖位于太湖东南部, 是一个平均水深不到 $1.2 \mathrm{~m}$ 的半封闭型浅水湖湾, 典型的草型湖区, 总面积 $131.0 \mathrm{~km}^{2}$, 沉水植被和浮叶植被是其主要水生植被类型, 分布面积分别占全湖湾总面积的 $73.6 \%$ 和 $18.3 \%{ }^{[1]}$. 温度是湖泊的重要环境参数之一, 是决定湖泊生物生命活动的重要物理因子 ${ }^{[2-3]}$, 对湖泊的群落结 构变化有着重要影响 ${ }^{[4]}$. 湖泊温度变化会对水生植被的代谢过程和生命周期产生重要影响, 从而改变水生 植被调控湖泊生态系统的能力 ${ }^{[5]}$, 因此研究浅水湖泊水温变化具有重要现实意义.

为了认识湖泊水温的分布和变化规律, 国内外开展了大量水温观测、模拟和预测的研究. 目前我国湖泊 水温观测主要分为两种, 即低频长期观测和高频短期观测 ${ }^{[6-9]}$. 研究表明太湖夏季存在水温日成层的现象且 可能对湖泊水质产生影响 ${ }^{[3,10-11]}$, 因此有必要对湖泊进行长期高频观测, 以研究浅水湖泊不同季节温度日变 化的差异. 相关水温模拟和预测的研究表明: 湖泊沉积物的温热过程可显著影响浅水湖泊的季节热量收 支 ${ }^{[12]}$; 沉积物的热量变化可对水温的日变化产生影响 ${ }^{[13]}$; 不考虑沉积物热库会导致夏季湖底水温模拟结果 偏高, 而冬季湖底水温模拟结果偏低 ${ }^{[14]}$; 湖泊夏季从大气中吸收的热量相当一部分储存在底部沉积物的热 活跃层, 这部分热量在秋季和冬季又重新释放回水体 ${ }^{[15]}$. 在浅水湖泊特别是其底部区域,沉积物对水温的 热效应值得关注 ${ }^{[16-17]}$, 东太湖为典型的浅水湖区, 太阳辐射可直达水底 ${ }^{[18]}$, 沉积物对太阳辐射的吸收以及水 一沉积物界面之间的热量交换必将对其水温变化产生影响, 因此进行东太湖水一沉积物界面热通量的计算 和研究为认识浅水湖泊的热过程提供依据.

本文利用 2013 年 11 月至 2015 年 10 月两年不同深度水体和沉积物温度高频观测数据, 结合东太湖表 层沉积物的热力学性质, 分析东太湖水温和水一沉积物界面热通量的变化规律, 探讨沉水植被和气象要素对 其影响, 以期为研究东太湖乃至浅水湖泊的水温变化和水温模型热边界以及认识水温与水生植物的相互影 响提供参考.

\section{1 研究方法}

\section{1 研究区域表层沉积物特点}

东太湖表层 $(10 \mathrm{~cm})$ 沉积物属于粉砂质黏土, 细粉砂 $(0.1 \sim 0.01 \mathrm{~mm})$ 和黏土 $(<0.01 \mathrm{~mm})$ 分别占比 $64.36 \%$ 和 $34.79 \%$, 二者之和超过 $99 \%$. 东太湖表层 $15 \mathrm{~cm}$ 沉积物的含水率和容重存在跃变现象, 随深度增 加, 含水率由 $70 \%$ 线性下降至 $30 \%$ 左右, 容重由 $1.2 \mathrm{~g} / \mathrm{cm}^{3}$ 线性增加到 $1.7 \mathrm{~g} / \mathrm{cm}^{3}$ 左右. 跃变层深度以下沉积 物含水率和容重变化不大 ${ }^{[19]}$.

东太湖表层沉积物主要由土壤基质和间隙水组成, 因此热力学性质计算时应考虑这两种组分. 根据已 有研究 ${ }^{[20-22]}$ 和东太湖表层沉积物的物理特性计算得到其土壤基质的体积热容为 $2.217 \times 10^{6} \mathrm{~J} /\left(\mathrm{m}^{3} \cdot{ }^{\circ} \mathrm{C}\right)$, 表 层沉积物的体积热容范围为 $2.809 \times 10^{6} \sim 3.597 \times 10^{6} \mathrm{~J} /\left(\mathrm{m}^{3} \cdot{ }^{\circ} \mathrm{C}\right)$, 位于一般湖泊沉积层的体积热容范围 $(1.4 \times$ $\left.10^{6} \sim 3.8 \times 10^{6} \mathrm{~J} /\left(\mathrm{m}^{3} \cdot{ }^{\circ} \mathrm{C}\right)\right)^{[23]}$ 偏高的部分. 东太湖表层沉积物的热传导系数和热扩散系数范围分别为 $0.743 \sim$ $1.186 \mathrm{~W} /\left(\mathrm{m} \cdot{ }^{\circ} \mathrm{C}\right)$ 和 $0.019 \sim 0.033 \mathrm{~m}^{2} / \mathrm{d}$, 位于一般湖泊沉积层的热扩散系数范围 $\left(0.01 \sim 0.11 \mathrm{~m}^{2} / \mathrm{d}\right)^{[24]}$ 偏低的 部分.

\section{2 观测方案与数据}

观测仪器为美国 Onset 公司的 Tidbit 温度存储器 (大小为 $3.0 \mathrm{~cm} \times 4.1 \mathrm{~cm} \times 1.7 \mathrm{~cm}$, 测量范围为 $-20 \sim$ $50^{\circ} \mathrm{C}$, 测量精度为 $\pm 0.001^{\circ} \mathrm{C}$; 观测时段为 2013 年 11 月至 2015 年 10 月, 观测时间间隔为 20 分钟; 观测地点 位于东太湖湖心 $\left(31.08083^{\circ} \mathrm{N}, 120.49751^{\circ} \mathrm{E}\right.$ ), 垂向上的观测点分别位于湖体表层 (水面以下 $40 \mathrm{~cm}$ 处, 表层 水温)、湖体底层 (水一沉积物界面以上 $10 \mathrm{~cm}$, 底层水温)、水一沉积物界面 (界面温度) 以及界面以下沉积物 $10 \mathrm{~cm}$ 处 (沉积物温度), 观测点位和观测层次如图 1 所示. 
观测期间逐日气温和风速数据来源于国家气象站东山基本站,2014 年 2 月 4 日至 10 日、2014 年 6 月 22 日至 28 日、2014 年 8 月 7 日至 13 日和 2014 年 12 月 17 日 23 日期间逐时气温、风速和太阳辐射数据来源于 微气象站( 位于太湖湖泊生态系统野外观测研究站东山分站).

2013 年 7 月 22 日至 28 日太湖持续高温天气期间,在上述观测点附近对沉水植被狐尾藻( Myriophyllum verticillatum L. ) 覆盖水域及无水生植被水域进行了不同深度 (水面以下 $10 、 20 、 30$ 和 $40 \mathrm{~cm}$ 处) 温度的同步 观测, 观测时间间隔为 $2 \mathrm{~min}$, 观测点水深 $1.1 \mathrm{~m}$, 植被为狐尾藻群落, 仪器投放处的狐尾藻生物量为 $2.6 \mathrm{~kg} / \mathrm{m}^{2}$, 覆盖度 $>85 \%$.
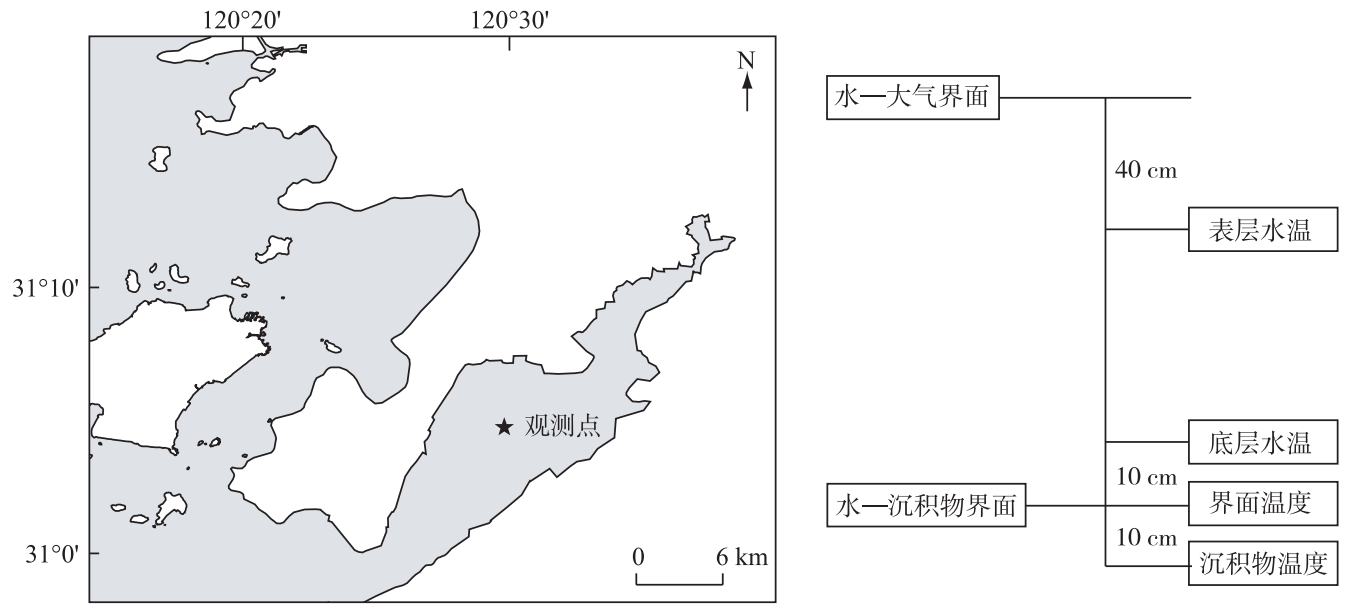

图 1 东太湖观测点位 $(\mathrm{a})$ 和观测层次示意图 $(\mathrm{b})$

Fig.1 Monitoring site (a) and layer diagram of monitoring (b) at East Lake Taihu

\section{3 数据处理与计算方法}

1.3.1 数据处理 为揭示各深度处温度日变化过程在各季节平均和年均间的差异, 对春、夏、秋、冬四季和全 年时段内每日各时刻温度取均值得到不同季节平均和年均 24 小时温度. 太湖位于北亚热带,因此本研究将 上年 12 月至本年 2 月、3-5 月、6-8 月、9-11 月划分为冬、春、夏、秋四季. 为考察年际间温度变化的异同 及影响因素, 结合观测情况, 以 2013 年 11 月至 2014 年 10 月和 2014 年 11 月至 2015 年 10 月为两个年变化 周期进行比较分析.

1.3.2 水一沉积物界面热通量 湖泊沉积物间隙水流速较小, 沉积物内部在垂向上主要通过热传导方式进行 热量传输, 水一沉积物界面热通量可基于一维热传导公式计算 ${ }^{[24]}$ :

$$
H_{\mathrm{SED}}=-k_{s}\left(\frac{\mathrm{d} T_{s}}{\mathrm{~d} z}\right)_{\text {WSI }}
$$

式中, $H_{\mathrm{SED}}$ 为水一沉积物界面热通量 $\left(\mathrm{W} / \mathrm{m}^{2}\right), k_{s}$ 为热传导系数 $\left(\mathrm{W} /\left(\mathrm{m} \cdot{ }^{\circ} \mathrm{C}\right)\right),\left(\frac{\mathrm{d} T_{s}}{\mathrm{~d} z}\right)_{\mathrm{WSI}}$ 为水一沉积物界面处 的温度梯度 $\left({ }^{\circ} \mathrm{C} / \mathrm{m}\right)$.

沉积物热传导系数的计算方法如下 ${ }^{[20]}$ :

$$
k_{s}=k_{d}^{1-\theta_{\text {sat }}} \cdot k_{0}^{\theta_{\text {sut }}}
$$

式中, $k_{d}$ 为土壤基质的导热率 $\left(2.0 \mathrm{~W} /\left(\mathrm{m} \cdot{ }^{\circ} \mathrm{C}\right)\right) ; k_{0}$ 为水的分子热传导系数 $\left(\left(0.0014 T_{\text {water }}+0.5668\right) \mathrm{W} /\right.$ $\left(\mathrm{m} \cdot{ }^{\circ} \mathrm{C}\right)$, 由参考文献 ${ }^{[22]}$ 和实验数据近似 $) ; \theta_{\text {sat }}$ 为表层沉积物含水率, 取均值 $50 \%$.

因此上述水一沉积物界面热通量计算公式的离散形式为:

$$
H_{\mathrm{SED}}=-\left[2^{\left(1-\theta_{\mathrm{sus}}\right)}\left(0.0014\left(T_{\mathrm{WSI}}+T_{\mathrm{S}-10}\right)+0.5668\right)^{\theta_{\mathrm{san}}}\right]\left(T_{\mathrm{WSI}}-T_{\mathrm{S}-10}\right) /(2 \Delta z)
$$

式中, $T_{\mathrm{WSI}}$ 为界面温度 $\left({ }^{\circ} \mathrm{C}\right), T_{\mathrm{S}-10}$ 为沉积物温度 $\left({ }^{\circ} \mathrm{C}\right), \Delta z$ 为表层沉积物深度 $(0.1 \mathrm{~m}) . H_{\mathrm{SED}}$ 值为正表示沉积物 为热源, 向湖体释放热量;值为负表示沉积物为热汇, 从湖体吸收热量. 


\section{2 结果与分析}

\subsection{4 年水体和沉积物温度的变化特征}

2.1 .1 日变化 各深度温度年均日变化过程及年均和季均 $0: 00$ 温度、升温时段(剩余时段为降温阶段) 和日 温度变幅如图 2 和表 1 所示. 各深度处年均 24 小时内温度变化过程均可分为升温和降温阶段: 东太湖水温 日变化多为横向 $\mathrm{S}$ 型, 表层水体从 4:00-6:00 开始升温到 13:00-14:00, 其后降温, 随水深增加, 温度日变 幅减小,升温过程后延,这一日变化过程反映了水温随太阳辐射的日变化而变化,表层水温的年均日变化过 程与鄱阳湖和春季的天目湖相似 ${ }^{[6-7]}$. 表层水温和底层水温春季和秋季日内升温时段与年均日内升温时段 基本相同,夏季升温过程延长, 冬季升温过程缩短. 界面温度日变化与底层水温相似但相对底层水温日变化 延迟,夏季和秋季的延迟相对春季和冬季小;沉积物温度年均日内升温时段为 13:00 至次日 2:00, 春季和夏 季升温过程较长, 秋季和冬季升温过程基本发生在夜间. 沿水深方向各季节平均日内温度变幅与年均日内 温度变幅的变化规律相同: 表层水温 $>$ 底层水温 $>$ 界面温度 $>$ 沉积物温度; 各深度处温度夏季平均日内变幅最 小,冬季平均日内变幅最大,这一差异可能源于不同季节湖泊总热量变化的不同.

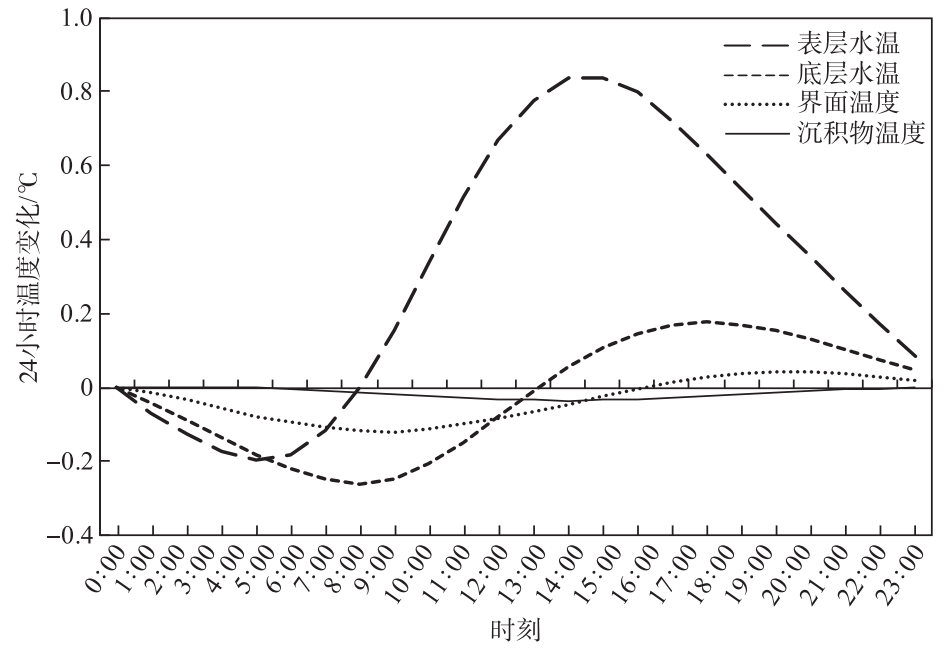

图 2 不同深度处年均 24 小时温度变化规律

Fig.2 Variations of temperatures in 24 hours at different depths

表 1 不同深度处年均和季均 24 小时温度变化特征

Tab.1 Daily variation features of seasonal-averaged and annual temperatures at different depths

\begin{tabular}{ccccccc}
\hline \multicolumn{1}{c}{ 时间 } & & 2014 年年均 & 2014 年春季 & 2014 年夏季 & 2014 年秋季 & 2014 年冬季 \\
\hline 起始 $0: 00$ 温度 $/{ }^{\circ} \mathrm{C}$ & 表层水温 & 17.93 & 17.03 & 27.00 & 20.40 & 6.65 \\
& 底层水温 & 17.71 & 16.86 & 26.16 & 20.46 & 6.71 \\
& 界面温度 & 17.66 & 16.50 & 25.77 & 20.59 & 7.61 \\
升温阶段 & 沉积物温度 & 17.83 & 16.04 & 25.05 & 21.15 & 8.59 \\
& 表层水温 & $4: 00-14: 00$ & $4: 00-13: 00$ & $6: 00-18: 00$ & $4: 00-13: 00$ & $6: 00-14: 00$ \\
& 底层水温 & $7: 00-17: 00$ & $8: 00-18: 00$ & $7: 00-18: 00$ & $7: 00-17: 00$ & $8: 00-17: 00$ \\
& 界面温度 & $8: 00-19: 00$ & $10: 00-23: 00$ & $7: 00-20: 00$ & $8: 00-18: 00$ & $11: 00-21: 00$ \\
& 沉积物温度 & $13: 00-2: 00$ & 几乎全天 & $9: 00-5: 00$ & $20: 00-23: 00$ & $16: 00-23: 00$ \\
& 表层水温 & 1.03 & 1.88 & 0.88 & 1.10 & 1.30 \\
& 底层水温 & 0.44 & 0.60 & 0.11 & 0.39 & 0.85 \\
& 界面温度 & 0.16 & 0.25 & 0.06 & 0.28 & 0.27 \\
& 沉积物温度 & 0.04 & 0.13 & 0.02 & 0.12 & 0.08 \\
\hline
\end{tabular}


2.1 .2 年变化 各深度处水体和沉积物温度年变化规律相同: 春季升温, 夏季温度最高, 秋季降温, 冬季温度 最低 (图 3), 该规律与其他亚热带区域湖泊或水库的表层水温变化规律一致 ${ }^{[18-20]} .2014$ 年 $1-12$ 月间,各月 底层水温日均值和同步表层水温日均值的相关系数分别为 $0.992 、 0.998 、 0.989 、 0.819 、 0.923 、 0.717 、 0.955$ 、 $0.926 、 0.977 、 0.976 、 0.981$ 和 0.994 ; 各月底层水温日均值与前一日表层水温日均值的相关系数则分别为 $0.932 、 0.952 、 0.978 、 0.851 、 0.970 、 0.898 、 0.973 、 0.982 、 0.972 、 0.952 、 0.953$ 和 0.967 . 在 $1-3$ 月和 $9-12$ 月间， 同步温度的相关性较非同步温度的相关性大,而其余时间内则相反,这一结果表明,在春季和夏季升温过程 中, 随深度增加, 温度变化延迟, 底层水温相对表层水温迟滞 1 天左右, 界面温度相对底层水温和沉积物温 度相对界面温度也存在这种迟滞现象, 这种延迟体现了东太湖作为浅水湖泊热量交换快速的特点, 与深水 湖库 3 4 个月的延迟 ${ }^{[8]}$ 显著不同; 秋季和冬季, 各深度层温度变化基本同步. 沉积物温度在 $1-2$ 月和 $10-$ 12 月高于界面温度, 沉积物为热源, 向水体放热; $3-9$ 月低于界面温度, 沉积物为热汇, 从水体吸热.

2013 年 11 月至 2014 年 10 月和 2014 年 11 月至 2015 年 10 月的两个年周期内各深度处温度年变化趋 势相同,但同比月均温存在差异, 如图 4 所示. 2015 年 $3 、 4$ 和 7 月, 不同深度处月均温相比 2014 年同比下 降, 其余月份同比基本为上升; 两年间,表层水温和底层水温年均同比分别上升 0.26 和 $0.21^{\circ} \mathrm{C}$, 界面温度和 沉积物温度仅上升 0.02 和 $0.07^{\circ} \mathrm{C}$; 各相邻深度处温度的月均值差异显著线性相关 $(P<0.01)$, 决定系数 $R^{2}>$ 0.8 ; 除 2013 年 12 月和 2014 年 5 月外, 同比表层水温的月均值差异与同步气温差呈显著正相关 $\left(R^{2}=0.881\right.$, $P<0.01), 12$ 月气温降低, 但东太湖各深度处温度均升高, 而 5 月则相反, 这种现象可能源于沉积物与湖泊水 体的热交换, 12 月湖泊为热源向水体放热, 5 月湖泊为热汇从水体吸热, 两个过程分别对湖泊的降温和升温 过程产生缓冲作用.

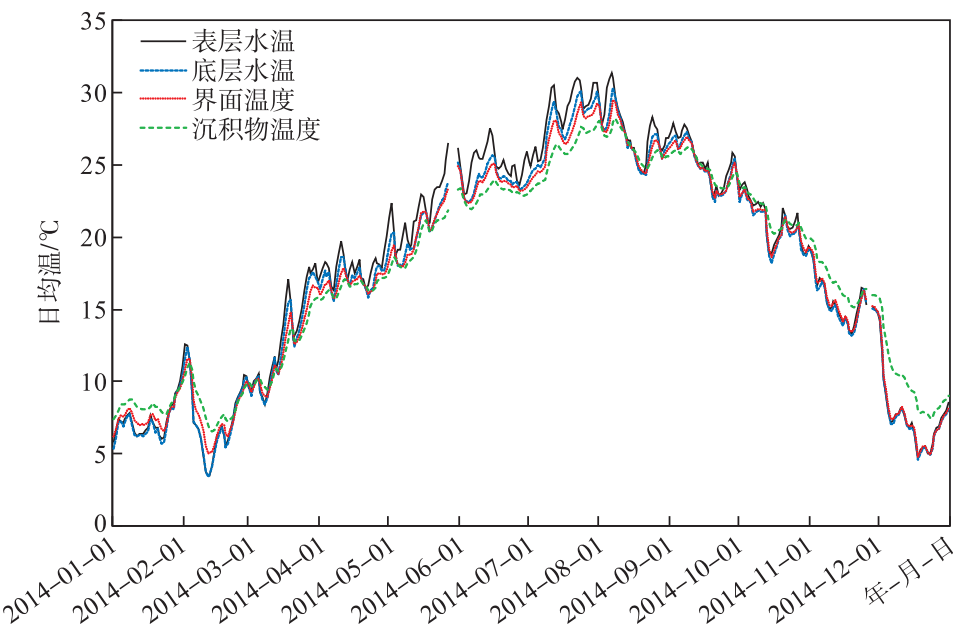

图 32014 年不同深度处温度逐日变化

Fig.3 Variations of monthly-averaged temperatures at different depths in 2014

\section{2 沉水植物对水温变化的影响}

对比观测期间: 湖泊水温从 21 日持续上升至 27 日,28 日略微下降,有植被区和无植被区水温在白天升 温过程中均出现了显著的日成层垂向分布现象, 与太湖相关报道 ${ }^{[10,25]}$ 相吻合; 有植被区水表下 $10 、 20 、 30$ 和 $40 \mathrm{~cm}$ 处日均水温均值分别为 $32.51 、 32.36 、 32.21$ 和 $32.09^{\circ} \mathrm{C}$, 日均水温最大增幅为 $2.99 、 2.95 、 2.95$ 和 $2.98{ }^{\circ} \mathrm{C}$; 无植被区水表下 $10 、 20 、 30$ 和 $40 \mathrm{~cm}$ 处日均水温均值分别为 $32.79 、 32.60 、 32.40$ 和 $32.26^{\circ} \mathrm{C}$, 日均水温最大增 幅为 $3.14 、 3.01 、 2.92$ 和 $2.95^{\circ} \mathrm{C}$.

除部分夜晚时间段外,有植被区各水层水温均低于无植被区, 降温幅度在太阳辐射达到高峰前后最大, 随深度增加, 水平水温差异减小 (图 5), 沉水植被对水表下 $10 、 20 、 30$ 和 $40 \mathrm{~cm}$ 处同层水温的平均降温比例 (水温差/无植被区水温) 分别为 $0.82 \% 、 0.73 \% 、 0.59 \%$ 和 $0.53 \%$, 有植被区水体日内升温过程随水深增加出 


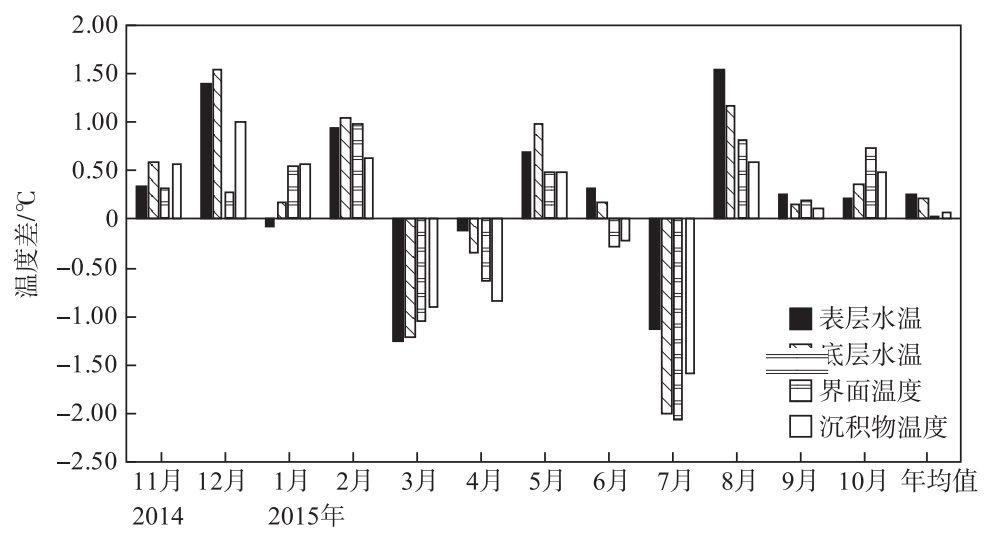

图 4 2014-2015 年不同深度处月均温度差

Fig.4 Differences of monthly-averaged temperatures at different depths from 2014 to 2015

现起始滞后和过程延长, 无植被区各水层水体升温过程基本同步; 有植被区水体垂向温度梯度低于无植被 的开敞水域 (图 5), 植被对水温垂向梯度的影响存在一定的滞后:无植被区滞后 1 小时的垂向水温差 (10 $40 \mathrm{~cm})$ 约为有植被区垂向水温差的 1.41 倍 $\left(R^{2}=0.827, P<0.01\right)$, 无植被区同步垂向水温差约为有植被区垂 向水温差的 1.37 倍 $\left(R^{2}=0.777, P<0.01\right)$.

\section{3 水一沉积物界面热通量}

2.3.1 热通量时间变化特征 东太湖水一沉积物界面热通量存在明显的日变化规律 (图 6): 全年、秋季和冬 季平均界面逐时热通量为正,沉积物向水体放热,年均日内从 8:00-19:00 放热减少, $19: 00$ 至次日 $8: 00$ 放 热增加, 通量日变幅为 $0.63 \times 10^{4} \mathrm{~J} /\left(\mathrm{m}^{2} \cdot \mathrm{h}\right)$; 秋季平均日变化与年均日变化规律相同, 通量日变幅为 $1.13 \times 10^{4}$ $\mathrm{J} /\left(\mathrm{m}^{2} \cdot \mathrm{h}\right)$; 冬季平均日变化曲线相对年均日变化曲线右移, $11: 00-21: 00$ 沉积物放热减少, $21: 00$ 至次日 $11: 00$ 放热增加, 通量日变幅为 $1.02 \times 10^{4} \mathrm{~J} /\left(\mathrm{m}^{2} \cdot \mathrm{h}\right)$; 春季平均和夏季平均逐时热通量为负值, 沉积物从水体 吸热,春季和夏季均自 $11: 00$ 吸热增加,通量日变幅分别为 $0.65 \times 10^{4}$ 和 $0.19 \times 10^{4} \mathrm{~J} /\left(\mathrm{m}^{2} \cdot \mathrm{h}\right)$.

界面热通量年变化规律呈正弦型(图 7), 2013 年 11 月 1 日至 2015 年 9 月 30 日的逐日热通量正弦曲线 拟合结果为: $H_{\mathrm{SED}}=1.049 \sin (($ Day +53.71$) \pi / 184.6)+0.130, R^{2}=0.660, P<0.001$; 逐日热通量每 $6 \sim 15$ 天 存在相对年变幅较小幅度的正弦式波动, 变化幅度分布在 $0.2 \times 10^{6} \sim 2.7 \times 10^{6} \mathrm{~J} /\left(\mathrm{m}^{2} \cdot \mathrm{d}\right) .2013$ 年 11 月至 2014 年 2 月,沉积物向水体放热, 为热源; $3-9$ 月从水体吸热, 为热汇;2014 年 10 月至 2015 年 2 月再次为热源向 水体放热; 其后至 9 月为热汇从水体吸热, 这一变化规律与此前基于温度曲线的分析和沉积物在温带、极地 附近湖泊的热通量研究结果 ${ }^{[15]}$ 一致.

2.3.2 热通量与不同深度处湖泊温度的关系 东太湖表层水温、底层水温、界面温度和沉积物温度的日均值 与逐日水一沉积物界面热通量均呈负相关, 相关系数分别为 $-0.704 、-0.689 、-0.654$ 和 $-0.567(P<0.05)$. 表 层日均水温和底层日均水温差值基本为正 (占总观测日数的 $87.5 \%$ ), 表层水体向底层水体传热, 随深度增 加,水温变幅减小, 水温变化对外界热通量变化的响应减弱. 比较表层水温和界面热通量的日变化曲线(图 2 和图 5) 发现, 春季平均、秋季平均、冬季平均和年均情形下, 表层水温最高温时落后于界面热通量最大值 4 小时, 夏季平均则落后 10 小时.

\section{4 水温变化和水一沉积物界面热通量的影响因素}

2.4.1 太阳辐射对水温变化和水一沉积物界面热通量的影响 太阳辐射与水一沉积物界面热通量年变化规律 均为正弦型, 但二者相位差为 3 个月, 表层沉积物热量变化主要受制于太阳辐射和水一沉积物界面热交换, 这种相位差表明沉积物作为湖泊热库, 其与水体之间的热交换对湖泊水体热量和水温变化的调节依赖并滞 后于太阳辐射的影响.

前文数据结果表明随水深增加, 水温逐渐降低, 年温度变幅减小, 这是由于太阳辐射在水体中的衰减和 

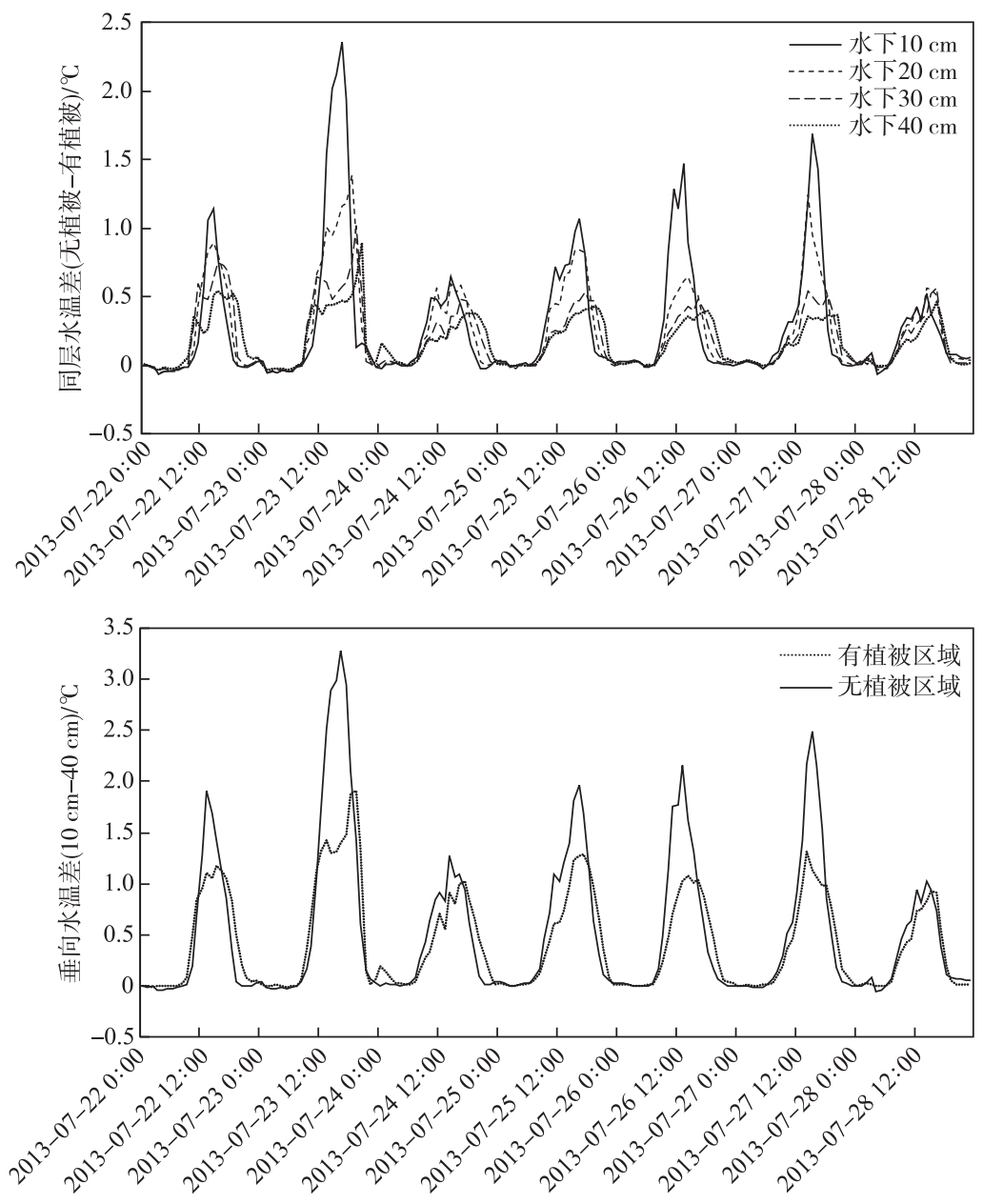

图 5 沉水植物对水平水温和垂直水温差的影响

Fig.5 Effects of submerged macrophytes on horizontal and vertical water temperature difference

水体传热所致. 2014 年 $1-12$ 月月均垂向水温差分别为 $0.212 、 0.135 、 0.485 、 0.668 、 1.238 、 1.076 、 0.979$ 、 $0.597 、 0.395 、 0.427 、 0.195$ 和 $0.080^{\circ} \mathrm{C}, 5$ 月最高, 2 月和 12 月较低, 与太阳辐射年变化规律稍有不同, 这一现 象可能与不断升高的太阳辐射使不同深度水体受热更均匀有关 ${ }^{[11]}$. 年均沉积物温度高于年均底层水温和 年均界面温度, 沉积物在一个周期年内为湖泊水体的热源, 由于东太湖地区真光层深度大 ${ }^{[18]}$, 沉积物向水体 传输的热量可能来源于其对太阳辐射的直接吸收.

2.4.2 气温对水温变化和水一沉积物界面热通量的影响 两年观测数据显示湖泊各深度处日均温的年变化 趋势均与日均气温的年变化趋势一致,沉积物温度变化略滞后, 这一结果与鄱阳湖 ${ }^{[6]}$ 、东湖 ${ }^{[26]}$ 、太湖 ${ }^{[9]}$ 的水 温研究结论相似. 日均表层水温、底层水温、界面温度和沉积物温度与日均气温的相关系数分别为 0.982 、 $0.973 、 0.963$ 和 $0.945(P<0.01)$, 随深度增加温度年变化越平缓, 相关性越弱, 这是因为气温决定着大气长波 辐射的强度和水一气界面显热交换的强度和方向 ${ }^{[27]}$, 影响湖泊热量的收支, 大气长波辐射与太阳辐射在水 体中均存在沿水深衰减的现象 ${ }^{[10]}$.

逐时气温与水一沉积物界面逐时热通量的变化大部分情况下镜像相似, 气温升高, 水体吸热, 沉积物向 水体放热减少或从水体吸热增加, 但不同天气状况会导致水体传热变化从而使水一沉积物界面热通量对气 温变化的响应不能同步. 外界气温持续下降时, 水一沉积物界面逐时热通量与逐时气温呈负相关, 2 月气温 


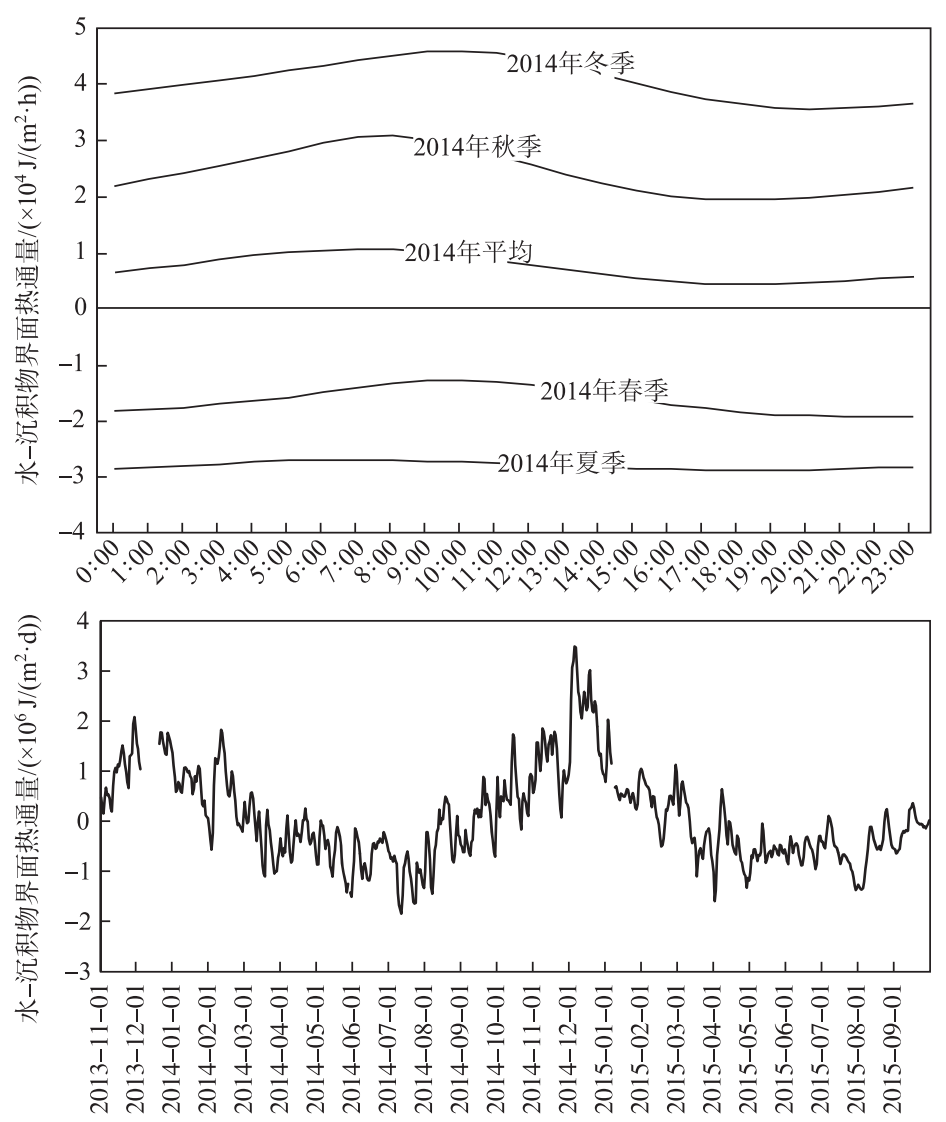

图 6 水一沉积物界面热通量日变化和年变化

Fig.6 Variations of hourly and diurnal heat fluxes at water-sediment interface

降低过程中, 沉积物为热源, 沉积物向水体传输热量增加, 8 月气温降低过程中, 沉积物为热汇, 沉积物从水 体吸收热量减少. 水一沉积物界面逐日热通量与逐日气温呈显著负相关 $(r=-0.728, P<0.05)$, 逐月热通量总 量与逐月气温呈负相关 $(r=-0.674, P<0.05)$, 逐月热通量总量与逐月气温差值 (当月一前月) 亦呈负相关 (强 于前一负相关关系, $r=-0.773, P<0.05)$, 热通量的变化相对气温变化滞后.

2.4.3 风速对水温变化和水一沉积物界面热通量的影响 风速影响水一气界面显热与潜热交换的强度 ${ }^{[27]}$, 风 速越大, 水体混合越快 ${ }^{[25]}$, 气温下降且风速相对较大时, 各深度处温度与时均风速呈一定的负相关关系, 风 速增加, 水体混合越剧烈, 水温随气温持续下降, 负相关性越强; 随深度增加风速对水体扰动的影响减小, 降 温幅度减小, 负相关性减弱 (表 2). 气温变化平稳且风速相对较小时, 不同深度处温度与时均风速呈正相关 关系, 随深度增加夏季相关性减弱, 冬季相关性增强 ${ }^{[28]}$.

2.4.4 水生植被与水温变化的关系 东太湖挺水植被分布面积减少, 浮叶植物和沉水植物分布面积持续扩 张, 荇菜 (Nymphoides indica) 、伊乐藻 (Elodea nuttallii) 和马来眼子菜 (Potamogeton malaianus) 等成为优势 种 ${ }^{[29]}$. 水生植物不但会吸收一定的热量, 还会通过阻挡太阳辐射的传播对水下光场等产生影响, 进而改变 水体吸收太阳辐射并升温的过程, 同时对水温垂向梯度及空间分布差异产生影响. 前述观测结果显示沉水 植物会降低水温以及表、底层水温的梯度, 但与此同时, 浮游植物能强化水体的热分层 ${ }^{[30-31]}$, 荇菜等浮叶植 物的遮光作用也能提高水体的光衰减率 ${ }^{[32]}$.

东太湖地区水生植物生物量 1 月最低, 3-8 月保持缓慢增长, 9 月最高, 伊乐藻生物量所占比例较 高 ${ }^{[29]}$, 这一变化相对水温变化滞后, 可能与伊乐藻最适生长温度为 $25^{\circ} \mathrm{C}$ 左右有关, $7-9$ 月为伊乐藻生长高 
峰期. 不同水生植物对水温变化的响应各有差异, 如菹草喜低温, 适宜生长温度为 $10 \sim 20^{\circ} \mathrm{C}$, 这些差异在东 太湖显著的水生植被群落结构演变 ${ }^{[1]}$ 中至关重要.

\section{表 2 不同温度指标及热通量与风速相关性分析}

Tab.2 Correlation analysis between different temperature indexes, heat fluxes at water-sediment interface and wind speed

\begin{tabular}{ccccc}
\hline Pearson 相关系数 & $\begin{array}{c}2014-02-04 \text { 至 02-10 } \\
\text { 冬季降温过程 } \\
\text { 平均风速 } 6.31 \mathrm{~m} / \mathrm{s}\end{array}$ & $\begin{array}{c}\text { 2014-06-22 至 06-28 } \\
\text { 夏至前后 } \\
\text { 平均风速 } 2.76 \mathrm{~m} / \mathrm{s}\end{array}$ & $\begin{array}{c}\text { 2014-08-07 至 08-13 } \\
\text { 夏季降温过程 } \\
\text { 平均风速 } 3.70 \mathrm{~m} / \mathrm{s}\end{array}$ & $\begin{array}{c}2014-12-17 \text { 至 12-23 } \\
\text { 冬至前后 }\end{array}$ \\
\hline 平均风速 $2.95 \mathrm{~m} / \mathrm{s}$ \\
表层水温 & -0.2304 & 0.3873 & -0.0741 & 0.4652 \\
底层水温 & -0.1867 & 0.3520 & -0.0521 & 0.4950 \\
界面温度 & -0.1253 & 0.3017 & -0.0677 & 0.5034 \\
沉积物温度 & -0.0947 & 0.1763 & -0.1292 & 0.1999 \\
表、底层水温差 & -0.3462 & 0.2583 & -0.1141 & -0.0536 \\
界面热通量 & 0.2005 & -0.4048 & 0.0116 & -0.3179 \\
\hline
\end{tabular}

\section{3 结论}

通过对东太湖水温变化和水一沉积物界面热通量的研究, 可以得出如下结论:

1) 东太湖各深度水体日升温过程随水深增加后延, 升温过程夏季延长, 冬季缩短; 年均和季均日温度变 幅: 表层水温 $>$ 底层水温 $>$ 界面温度 $>$ 沉积物温度, 各深度处温度日变幅夏季最小, 冬季最大; 春季和夏季升温 过程中各深度日均温变化沿水深存在约 1 天的延迟,秋季和冬季无此现象;2015 年和 2014 年温度年变化趋 势相同, 同比月均温差与气温差呈线性相关.

2) 界面热通量平均日变化和年变化均呈正弦型, 日内从 8:00-19:00 放热增加或吸热减少, 19:00 至次 日 8:00 放热减少或吸热增加;年内从 3-9 月从水体吸收热量, 为热汇, 10 月至次年 2 月向水体释放热量, 为热源; 东太湖沉积物全年为湖泊的热源, 热量可能源于沉积物对太阳辐射的直接吸收; 逐日热通量每 $6 \sim$ 15 天存在相对年变化较小振幅的正弦式波动.

3) 水温和水一沉积物界面热通量的变化主要受到太阳辐射和气温的影响, 且二者对太阳辐射和气温的 响应具有迟滞性; 界面热通量与气温和水温均呈负相关, 且这种相关性也具有迟滞性, 界面热通量主要作用 为缓冲湖泊水体的热量变化;夏季,沉水植物能降低湖泊表层水温和垂向水温差.

\section{4 参考文献}

[ 1 ] Gu XH, Zhang SZ, Bai XL et al. Evolution of community structure of aquatic macrophytes in East Taihu Lakeland its wetlands. Acta Ecologica Sinica, 2005, 25(7): 1541-1548. [谷孝鸿, 张圣照, 白秀玲等. 东太湖水生植物群落结构的 演变及其沼泽化. 生态学报, 2005, 25(7): 1541-1548.]

[ 2 ] Kong FX, Gao G. Hypothesis on cyanobacteria bloom-forming mechanism in large shallow eutrophic lakes. Acta Ecologica Sinica , 2005, 25(3) : 589-595. [孔繁翔, 高光. 大型浅水富营养化湖泊中蓝藻水华形成机理的思考. 生态学报, $2005,25(3): 589-595$. ]

[ 3 ] Zhao LL, Zhu MY, Feng LQ et al. Stratification and its driving factors of water physicochemical variables in large, shallow Lake Taihu. J Lake Sci, 2011, 23(4) : 649-656. DOI: 10.18307/2011.0423. [ 赵林林, 朱梦圆, 冯龙庆. 太湖水体理 化指标在夏季短时间尺度上的分层及其控制因素. 湖泊科学, 2011, 23(4) : 649-656.]

[ 4 ] Chen Q, Han HJ, Zhai SJ et al. Influence of solar radiation and water temperature on chlorophyll-a levels in Lake Taihu, China. Acta Scientiae Circumstantiae, 2009, 29(1): 199-206. [陈桥, 韩红娟, 翟水晶等. 太湖地区太阳辐射与水温 的变化特征及其对叶绿素 $\mathrm{a}$ 的影响. 环境科学学报, 2009, 29(1): 199-206.]

[ 5 ] He J, Gu XH, Liu GF. Aquatic macrophytes in East Lake Taihu and its interaction with water environment. J Lake Sci, 2008, 20 (6) : 790-795. DOI: 10.18307/2008.0618. [何俊, 谷孝鸿, 刘国锋. 东太湖水生植物及其与环境的相互作 用. 湖泊科学, $2008, \mathbf{2 0}(6)$ : 790-795. ] 
[ 6 ] Xu HS, Ouyang XF. Water temperature in Poyang Lake. Oceanologia et Limnologia Sinica, 1989, 20(4) : 343-353. [徐 火生, 欧阳幸福. 鄱阳湖的水温. 海洋与湖沼, 1989, 20(4) : 343-353.]

[ 7 ] Zhang YL, Chen WM, Yang DT et al. Monitoring and analysis of thermodynamic status of Tianmu Lake. Advances in Water Science, 2004, 15(1): 61-67. [张运林, 陈伟民, 杨顶田等. 天目湖热力学状况的监测与分析. 水科学进展, 2004, $15(1): 61-67$.

[ 8 ] Liu ML, Wu ZX, He JB et al. Thermodynamics and stratification in Xin'anjiang Reservoir (Lake Qiandao). J Lake Sci, 2014, 26(3) : 447-454. DOI: 10.18307/2014.0316. [刘明亮, 吴志旭, 何剑波等. 新安江水库(千岛湖) 热力学状况 及热力分层研究. 湖泊科学, $2014,26(3): 447-454$. ]

[ 9 ] Chen SL, Lu JW, Shen JQ. Study on temporal and spatial variation of water temperature in Taihu Lake. Jiangsu Water Resources, 2009, (3) : 38-39. [陈绍良, 陆建伟, 沈建强. 太湖水体温度时空变化规律的初步研究. 江苏水利, 2009, (3) : 38-39.]

[10] Zhang YC, Qian X, Ishikawa Tadaharu et al. Study on diurnal stratification in a typical shallow lake-Taihu Lake. Sichuan Environment, 2008, 27(3): 45-48. [张玉超, 钱新, 石川忠晴等. 浅水型湖泊水温日成层现象的初步探 讨一以太湖为例. 四川环境, 2008, 27(3): 45-48.]

[11] Zhao LL, Zhu GW, Chen YF et al. Vertical distribution characteristics of Lake Taihu and its influencing factors. Advances in Water Science, 2011, 22(6): 844-850. [ 赵林林, 朱广伟, 陈元芳等. 太湖水体水温垂向分层特征及其影响因素. 水科学进展, 2011, 22(6): 844-850.]

[12] Birge EA, Juday C, March HW. The temperature of the bottom deposits of Lake Mendota.. [s.n], 1928.

[13] Fang X, Stefan HG. Dynamics of heat exchange between sediment and water in a lake. Water Resources Research, 1996,32 (6) : 1719-1727.

[14] Golosov S, Kirillin G. A parameterized model of heat storage by lake sediments. Environmental Modelling \& Software, 2010, $25(6)$ : 793-801.

[15] Pivovarov AA, Vilim E, Greenberg P eds. Thermal conditions in freezing lakes and rivers. New York: Wiley \& Sons, 1973.

[16] Bengtsson L, Malm J, Terzhevik A et al. Field investigation of winter thermo-and hydrodynamics in a small Karelian lake. Limnology and Oceanography, 1996, 41(7) : 1502-1513.

[17] Malm J, Terzhevik A, Bengtsson L et al. Temperature and salt content regimes in three shallow ice-covered lakes. Hydrology Research, 1997, 28(2) : 99-128.

[18] Zhang YL, Feng S, Ma RH et al. Spatial pattern of euphotic depth and estimation of phytoplankton primary production in Lake Taihu in autumn 2004. J Lake Sci, 2008, 20(3) : 380-388. DOI:10.18307/2008.0319. [张运林, 冯胜, 马荣华 等. 太湖秋季真光层深度空间分布及浮游植物初级生产力的估算. 湖泊科学, 2008, 20(3) : 380-388. ]

[19] Qin BQ, Hu WP, Chen WM et al eds. Water environment evolution process and mechanism of Taihu Lake. Beijing: Science Press, 2004. [秦伯强, 胡维平, 陈伟民等. 太湖水环境演化过程与机理. 北京: 科学出版社, 2004.]

[20] Sun SF, Yan JF, Xia N et al. Study on heat transfer between land surface and atmosphere. Scientia Sinica Physica, Mechanica \& Astronomica, 2008, 38(6):704-713. [孙菽芬, 颜金风, 夏南等. 陆面水体与大气之间的热传输研究. 中 国科学: 物理学·学·天文学, 2008, 38(6): 704-713.]

[21] Li Y, Shao MA, Wang WY et al. Influence of soil textures on the thermal properties. Transactions of the Chinese Society of Agricultural Engineering, 2003, 19(4): 62-65. [李毅, 邵明安, 王文焰等. 质地对土壤热性质的影响研究. 农业工 程学报, 2003, 19(4): 62-65.]

[22] Liu JF, Zeng DL, Liu C et al. Molecular dynamics simulations of conductivity. Journal of Engineering Thermophysics, $2007,28(2)$ : 196-198. [刘娟芳, 曾丹苓, 刘朝等. 水导热系数的分子动力学模拟. 工程热物理学报, 2007,28 (2) : 196-198.]

[23] Fang X, Stefan HG. Temperature variability in lake sediments. Water Resources Research, 1998, 34(4) : 717-729.

[24] Liu F. Research on three-dimensional lake temperature model based on the heat flux of water-sediment interface [Dissertation ]. Wuhan: Huazhong University of Science and Technology, 2014. [刘凤. 基于水一沉积物界面热通量的湖泊三维 水温模型研究 [学位论文]. 武汉: 华中科技大学, 2014.]

[25] Zhang YC, Qian X, Qian Y et al. Field measurement and analysis on diurnal stratification in Taihu Lake. Environmental Science and Management, 2008, 33(6): 117-121. [张玉超, 钱新, 钱瑜等. 太湖水温分层现象的监测与分析. 环境 
科学与管理, 2008, 33(6): 117-121.]

[26] Wang XL, Kang L, Xiong QL. Relationships between water temperature and air temperature. Fifth China Water Forum, 2007. [王学立, 康玲, 熊其玲. 东湖水温与气温相互关系研究. 第五届中国水论坛, 2007.]

[27] She FN, Cai QM, Xu JY. Influence of temperature model and meteorological parameters on water temperature. Oceanologia et Limnologia Sinica, 1993, 24(4) : 393-399. [余丰宁, 蔡启铭, 徐勇积. 太湖水温模型和气象参数对水温的影响. 海洋与湖沼, 1993, 24(4) : 393-399.]

[28] Cheng X, Wang YW, Hu C et al. The lake-air exchange simulation of a lake model over eastern Taihu Lake based on the E-Eturbulent kinetic energy closure thermodynamic process. Acta Meteorologica Sinica, 2016, 74(4): 633-645. [程昕, 王咏薇, 胡诚等. 应用 $\mathrm{E}-\varepsilon$ 湍流动能闭合湖泊热力学过程模型对东太湖湖-气交换的模拟. 气象学报, 2016,74 (4) : 633-645.]

[29] Zhao K, Zhou YF, Jiang ZL et al. Changes of aquatic vegetation in Lake Taihu since 1960s. J Lake Sci, 2017, 29(2) : 351-362. DOI: 10.18307/2017.0211. [赵凯, 周彦锋, 蒋兆林等. 1960 年以来太湖水生植被演变. 湖泊科学, 2017, 29(2) : 351-362.]

[30] Sathyendranath S, Gouveia AD, Shetye SR et al. Biological control of surface temperature in the Arabian Sea. Nature, 1991, 349(6304) : 54-56.

[31] Zhai L, Platt T, Tang C et al. Phytoplankton phenology on the Scotian Shelf. Ices Journal of Marine Science, 2011,68 (4) : 781-791.

[32] Wang L, Wang GX, Tang XY et al. Inhibitory effects of different types aquatic macrophyte communities on blue-green algae. Chinese Journal of Ecology, 2009, 28 (12) : 2567-2573. [汪丽, 王国祥, 唐晓燕等. 不同类型水生植物群落对蓝 绿藻类的抑制作用. 生态学杂志, 2009, 28(12) : 2567-2573.] 